\title{
REFLEKSI PEMBERDAYAAN MASYARAKAT DALAM TUGAS GURU PENDIDIKAN AGAMA BUDDHA MELALUI PEMBINA AGAMA (GURU TIDAK TETAP) DI WONOGIRI
}

\author{
Hesti Sadtyadi \\ Sekolah Tinggi Agama Buddha Raden Wijaya Wonogiri \\ 15hestisadtyadi@gmail.com
}

\begin{abstract}
The purpose of this study was to investigate the implementation of the learning is done by people who become temporary teachers Buddhist education in an effort to meet the needs of the number of teachers who have not been fulfilled, the task execution, knowing temporary teachers in carrying out his duties as a teacher of Buddhist education. This research is a mix research. The result of research, indicate that the implementation of the learning undertaken by temporary teachers of Buddhist education in an effort to meet the needs of the teacher is the optimal number, and All teachers have done their job well, with components that should receive special attention is in the use of media and or learning strategies. If the evaluation is done thoroughly in the process of learning plans then seen the incomplete learning plan performed as in the case of making worksheets, clarity sources, lack of subject content validity, and if it is seen only in the process of learning plans in particular RPP (Learning Implementation Plan), specifically on learning plan in the classroom, regardless of other aspects) resulting deficiencies in the methods and learning strategies are used.
\end{abstract}

Keywords: Reflection, The Teacher Precarious, The Task

\begin{abstract}
Abstrak
Tujuan penelitian ini adalah untuk mengetahui pelaksanaan pembelajaran yang dilakukan oleh masyarakat yang menjadi guru tidak tetap pendidikan agama Buddha dalam upaya memenubi jumlah kebutuhan guru yang belum tercukupi, mengetahui pelaksanaan tugas guru tidak tetap dalam menjalankan tugasnya sebagai guru pendidikan agama Buddha. Penelitian ini merupakan penelitian mix. Hasil penelitian, menunjukkan bahwa pelaksanaan pembelajaran yang dilakukan oleb guru tidak tetap pendidikan agama Buddha dalam upaya memenubi jumlab kebutuhan guru cukup optimal, dan Selurub guru telab menjalankan tugasnya dengan baik, dengan komponen yang harus mendapat perhatian secara kbusus adalah dalam hal penggunaan media dan atau strategi belajar. Kurang lengkapnya rencana pembelajran yang dilakukan seperti dalam hal pembuatan LKS, kejelasan sumber, belum adanya pokok bahasan validitas isi, dan jika dilibat hanya pada proses rencana pembelajaran pada khususnya $R P P$ (rencana pelaksanaan pembelajaran), khusus pada rencana pembelajaran dalam kelas, dengan tanpa melihat aspek yang lain) dihasilkan kekurangan dalam hal metode dan strategi pembelajaran yang dipergunakan.
\end{abstract}

Kata Kunci: Refleksi, Guru Tidak Tetap, Tugas

Permalink/DOI: http://dx.doi.org/10.18326/infsl3.v10i2.405-426 


\section{Pendahuluan}

Pendidikan agama memiliki peran penting dalam membangun karakter sosial masyarakatnya. Peran penting ini seiring dengan Undang-Undang No. 20 Tahun 2003 tentang Sistem Pendidikan Nasional, pasal 3, yang menyebutkan bahwa "Pendidikan nasional berfungsi mengembangkan dan membentuk watak serta peradaban bangsa yang bermartabat dalam rangka mencerdaskan kehidupan bangsa, bertujuan untuk berkembangnya potensi peserta didik agar menjadi manusia yang beriman dan bertakwa kepada Tuhan Yang Maha Esa, berakhlak mulia, sehat, berilmu, cakap, kreatif, mandiri, dan menjadi warga negara yang demokratis serta bertanggung jawab. Rumusan tujuan pendidikan nasional tersebut memberikan gambaran bahwa, pendidikan nasional di Indonesia harus mampu mewujudkan apa yang di cita-citakan. Salah satu bentuk komponen pendidikan merupakan pendidikan agama.

Pendidikan agama harus menjadi rujukan utama (core values) dan menjiwai seluruh proses pendidikan dan pengembangan ilmu pengetahuan dan teknologi, pendidikan karakter, kewirausahaan, dan ekonomi kreatif dalam menjawab dinamika tantangan globalisasi. Pendidikan agama di sekolah seharusnya memberikan warna bagi lulusan pendidikannya, khususnya dalam merespon segala tuntutan perubahan dan dapat dipandang sebagai acuan nilai-nilai keadilan dan kebenaran, dan tidak semata hanya sebagai pelengkap.

Perlu pula diperhatikan prioritas dalam Pembangunan Nasional yang dituangkan secara yuridis formal dalam Rencana Pembangunan Jangka Panjang (RPJP) Nasional Tahun 2005-2025 (UU Nomor 17 Tahun 2007), yaitu mewujudkan masyarakat berakhlak mulia, bermoral, beretika, berbudaya, dan beradab berdasarkan Falsafah Pancasila. Hal ini memberikan gambaran bahwa tema prioritas pembangunan pendidikan adalah peningkatan mutu pendidikan.

Memperhatikan peraturan perundangan, maupun rencana pembangunan bangsa ini, menunjukkan tumpuan utama memberikan dasar pada pendidikan agama. Agama merupakan kunci dan landasan dalam mencapai cita-cita bangsa. Tetapi yang menjadi permasalahan adalah, proses dalam pendidikan agama tidaklah tepat, jika hanya dilakukan dengan asal-asalan saja. 
Pendidikan agama yang saat ini telah berlangsung, khususnya untuk pendidikan agama Buddha, memiliki tantangan yang sangat mendasar, dan mendalam. Mendasar berkaitan dengan proses pelaksanaan yang tidak sejalan dengan yang seharusnya dilakukan dalam pendidikan. Pendidikan agama Buddha khususnya, memiliki keterbatasan dengan guru agamanya. Guru pendidikan agama Buddha memiliki siswa yang relatif sedikit, tetapi tidak terkumpul dalam satu lembaga pendidikan, tetapi keberadaan mereka terpecah dalam berbagai lembaga pendidikan yang berbeda dengan jarak yang relatif berjauhan, sehingga keadaan ini akan menyebabkan mutu dalam pendidikan agama menjadi kurang sempurna.

Seorang guru agama Buddha dalam melaksanakan tugasnya akan melaksanakan tugas yang tidak menetap, akan selalu berpindah dari satu sekolah ke sekolah yang lain, sehingga tugas rutin mereka seperti sebuah trayek kendaraan umum. Dalam posisi yang lain guru pendidikan agama Buddha dituntut memiliki kinerja seperti guru yang lain dalam proses pembelajarannya, termasuk dalam hal memperoleh kesejahteraanya, seperti sertifikasi.

Sebagai fakta aktual jumlah guru agama Buddha yang tidak akan pernah bertambah jumlahnya, karena keterbatasan siswa, serta tidak mungkin dapat dilayani oleh guru yang terbatas tersebut, karena jarak dan wilayah tugas yang menjadi kendala. Sebagai salah satu bentuk cara dalam membantu memecahkan permasalahan tersebut adalah melalui program dari sekolah tingggi agama Buddha, melalui pemberdayaan masyarakatnya, dalam wujud Kuliah Kerja Nyata mahasiswa, dengan program pemberdayaan masyarakatnya, melalui pembina agama. Melalui kuliah kerja nyata, yang merupakan salah satu program pengabdian kepada masyarakat, maka dapat diwujudkan salah satunya adalah pembina agama Buddha. Pembina agama Buddha dapat berasal dari tokoh agama yang dianggap memiliki kemampuan dalam melakukan pembinaan agama khususnya untuk pendidikan agama.

Hal ini memberikan gambaran akan terdapat kendala dan permasalahan berikutnya, yakni mutu pendidikan agama tersebut. Bagaimana tidak menjadi masalah jika guru yang mengajar bukanlah berasal dari guru yang memiliki tugas dan fungsinya, 
artinya mereka berpeluang tidak memiliki kompetensi yang sesuai dengan bidangnya, tetapi setidaknya solusi yang dilakukan dapat membantu dalam memberikan penyelesaian tahap awal, dengan memperhatikan permasalahan utama yakni belum meratanya guru pendidikan agama Buddha dalam satu wilayah atau dengan kata lain masih kurangnya guru. Bappenas menyampaikan, perlunya pemerataan distribusi guru serta meningkatkan profesionalisme mereka (Armida S. Alisjahbana, et al, 2010: 43).

Tidak meratanya guru dalam sejumlah wilayah sekaligus menunjukkan adanya permasalahan kritis seperti disampaikan oleh Danim (2002: 168), yang mengatakan bahwa salah satu ciri krisis pendidikan Indonesia adalah guru belum mampu menunjukkan kinerjanya (work performance) yang memadai. Berarti pelaksanaan tugas guru belum optimal. Memperhatikan kinerja guru pendidikan agama Buddha berarti memfokuskan pada peran tugas dan fungsi guru. Dalam konteks ini, peran guru menjadi kunci utama. Peran guru terhadap siswa, dalam hal ini adalah tugas guru dalam mendidik, mengajar, melatih, maupun membimbing siswa. Menunjukkan bahwa guru memiliki tanggung jawab terbesar dalam keberhasilan siswa, melalui tugas yang terletak pada beban tugas guru tersebut. Berarti keberhasilan siswa sangat ditentukan oleh guru. Senada dengan kenyataan tersebut seperti hasil penelitian dalam Projek Hamilton, bahwa guru berperan dalam keberhasilan siswa melalui proses pendidikan, dan dapat menjadi faktor utama dalam semua keberhasilan. Berarti perlunya kinerja yang baik (Gordon, et all, 2006: 13). Didukung pula dengan hasil penelitian Daniel Suryadarma, Daniel Suryadarma, Asep Suryahadi \& Sudarmo Sumarto, (2005: 8) yang menyebutkan bahwa guru-guru mempunyai pengaruh yang paling penting terhadap kemajuan siswa, bahkan lebih penting daripada status sosial ekonomi dan lokasi sekolah.

Disampaikan pula oleh Amin \& Khan, (2009), bahwa guru merupakan kunci dalam sistem pendidikan, tetapi secara umum memiliki permasalahan rendahnya kualitas pengajaran, kualitas pendidikan, praktek pengajaran, serta tidak adanya sistem pemantauan yang layak atau pengawasan yang efektif, sementara harus memiliki pemahaman atas aspek-aspek efektifitas dalam mengajar, metodologi pengajaran, psikologi 
pendidikan, penggunaan bantuan audio-visual, teknik evaluasi dan lainnya.

Berkaitan dengan hal tersebut mengkaji guru agama Buddha yang terkait dengan sumber permasalahannya adalah kualifikasi pendidikan, pemerataan guru antar daerah, maupun hasil mutu pendidikan. Berdasarkan data dalam lingkup yang sempit sebagai sampel adalah guru pendidikan agama Buddha di wilayah kabupaten Wonogiri berjumlah 4 orang guru PNS, dengan jumlah siswa +/- 109 siswa, tetapi bentuk permasalahan ini tidak dapat diatasi dengan membagi jumlah siswa dengan guru, sehingga dihasilkan rasio $1: 28$, karena terdapat permasalahan pokok atau utama yaitu Siswa dengan jumlah 109 tersebut tersebar dalam wilayah kabupaten Wonogiri, jika guru agama Buddha tersebut harus melakukan perjalanan dari satu wilayah ke wilayah yang lain, Berarti tidak mungkin kualifikasi pelaksanaan tugas pokok dan fungsi di jalankan dengan sempurna.

Bentuk penyelesaian sementara yang digunakan dalam mengatasi kendala adalah dengan menempatkan guru tidak tetap, atau alumni Sekolah Tinggi Agama Buddha yang belum terangkat sebagai guru. Sehingga timbul permasalahan baru, karena mereka tidak mendapatkan penghasilan atau gaji, dan hanya mendapatkan ganti transport. Gambaran ini sekaligus memberikan gambaran bahwa dimungkinkan kinerja mereka akan menjadi kurang sempurna atau tidak efektif, karena hanya menjadi cara penyelesaian masalah dalam memenuhi kualifikasi dalam pemerataan kekurangan tenaga pendidik. Sehingga timbul permasalahan yang perlu dilakukan pengkajian yaitu bagaimanakah pelaksanaan program pembelajaran yang dilakukan oleh guru tidak tetap pendidikan agama Buddha di wilayah wonogiri.

\section{Metode Penelitian}

Penelitian ini merupakan penelitian kuantitatif-kualitatif, dengan subjek penelitian adalah guru pendidikan agama Buddha tidak tetap di wilayah Wonogiri. Populasi penelitian berjumlah sepuluh orang guru tidak tetap. Variabel penelitian adalah pelaksanaan tugas dalam program pembelajaran yang dilaksanakan guru tersebut. 
Pengumpulan data dilakukan dengan melalui pengamatan langsung kepada guru tidak tetap, wawancara, dan pengisian kuesioner. Tahap penelitian awal dilakukan dengan pengamatan atau observasi. Data dikumpulkan sejak tahun 2007, sehingga data yang didapat bukan hanya merupakan kejadian yang tidak disengaja, tatapi sekaligus merupakan kebiasaan yang terjadi pada guru tersebut. Setelah tahap observasi dilakukan tahap selanjutnya dengan wawancara kepada guru tersebut untuk menanyakan halhal yang kiranya dapat memperjelas, segala sesuatu yang dianggap merupakan permasalahan. Selanjutnya guru diminta untuk mengisi kuesioner sebagai penilian diri dalam kaitannya dengan pelaksanaan tugas pembelajaran yang dilaksanakannya.

Dalam kaitannya dengan kuesioner atau instrumen penilaian diri yang dibuat peneliti, dilakukan pula dengan teknik penilaian ahli, sehingga instrumen yang digunakan benar, merupakan instrumen yang dapat digunakan untuk memberikan penilaian berkaitan dengan pelaksanaan pembelajaran oleh guru tersebut. Pembuatan instrumen dilakukan dengan kualifikasi (1). Kesesuaian dengan tujuan, (2) Kesesuaian dan kejelasan konten (3) Mempergunakan standar prosedur yang jelas, (4) Mempergunakan standar atau skala penilaian yang jelas. Dalam kaitan dengan analisis diskriptif kualitatif digunakan untuk menganalisis data pengamatan, dan analisis diskriptif kuantitatif dengan tabulasi untuk melihat kecenderungan pelaksanaan pembelajaran yang dilakukan guru tidak tetap tersebut.

\section{Hasil Penelitian}

Melalui hasil telaah teoritik komponen guru pendidikan agama Buddha dalam hal ini terdiri dari tugas pokok dan fungsi guru pendidikan agama Buddha, secara khusus dalam bidang tugas guru dalam mengajar dan persiapannya, tersebut dijadikan acuan dalam menyusun kisi-kisi instrumen, yang dijabarkan dalam indikatorindikatornya. Instrumen tersebut terdiri dari instrumen identitas dan instrumen penilaian tugas guru dalam mengajar dan persiapannya. Instrumen identitas digunakan untuk melihat kelengkapan dokumen dan kesiapan guru dalam melaksanakan tugasnya. Instrumen pelaksanaan tugas guru dalam mengajar digunakan sebagai 
instrumen penilaian terhadap pelaksanaan tugas keguruannya, dan instrumen inilah yang akan dijadikan dasar sebagai landasan dalam refleksi dan penilaian terhadap pelaksanaan tugas guru pendidikan agama Buddha tersebut.

Angket atau instrumen identitas merupakan instrumen pelengkap, untuk instrumen pelaksanaan tugas guru pendidikan agama Buddha yang menanyakan identitas diri, beserta kelengkapan persiapan dan penunjang pelaksanaan kerja. Instrumen identitas bersifat sebagai pendukung dalam penilaian tugas guru pendidikan agama Buddha.

Melalui teknik Delphi tahap I dihasilkan saran dan masukan sehingga dilakukan revisi kisi-kisi serta instrumen tugas guru pendidikan agama Buddha tahap I. Sebagai wujudnya adalah instrumen identitas, tetap seperti dalam rencana, dan instrumen penilaian tugas guru pendidikan agama Buddha, dengan jumlah faktor tugas guru berjumlah 5, dan terdiri dari 15 indikator. Waktu yang disediakan untuk menyelesaikan instrumen tidak dibatasi, namun diharapkan subjek dapat menyelesaikan instrumen kurang lebih 60 menit.

Berdasarkan instrumen yang telah disusun dan dilakukan pengkajian melalui teknik Delphi tahap I, dilanjutkan uji keterbacaan. Melalui uji keterbacaan akan tampak hal-hal yang harus dirumuskan ulang, dan dilakukan melalui mekanisme delphi ke dua. Melalui Delphi inilah akhirnya tersusun isntrumen atau angket untuk memberikan refleksi ataupun penilaian pelaksanaan tugas guru pendidikan agama Buddha tersebut.

Tahapan dalam upaya penyusunan pernyataan dilakukan berdasarkan kisi-kisi yang telah disusun, dilanjutkan menyusun pernyataan atau instrumen dan uji keterbacaan, yang dilakukan setelah Delphi tahap pertama sekaligus untuk mendapatkan kesesuaian, antara pernyataan instrumen dengan tugas guru pendidikan agama Buddha.

Instrumen tugas guru pendidikan agama Buddha yang digunakan sebagai upaya dalam melakukan refleksi mengacu pada model skala Likert untuk mengukur sikap, dalam wujud sikap kerja 
dalam pelaksanaan tugas guru guru pendidikan agama Buddha khususnya dalam bidang pengajaran, melalui kesiapannya dalam tugas mengajar, dengan konsentrasi utama dalam hal kesiapan mengajar. Skala yang disusun merupakan pengembangan dari instrumen sikap dan observasi kinerja, yang berwujud instrumen memiliki skala 1 sampai dengan 5. Sedangkan instrumen identitas digunakan sebagai bentuk evaluasi kesesuaian dalam memberikan jawaban instrumen penilaian tugas. Penelaahan pernyataan dilakukan melalui tahapan telaah teori, uji keterbacaan, Delphi, diskusi, dan konsultasi, yang dilakukan untuk memperoleh butir pernyataan yang valid.

Validasi praktisi yang dilakukan oleh sejumlah pemakai yang menguasi bidangnya, yang juga merupakan validasi isi, dilakukan setelah dengan teknik Delphi, dengan cara melakukan telaah dengan pihak pengguna instrumen yang terdiri dari guru maupun dosen.

Dalam validasi praktisi, dihasilkan bahwa secara umum angket dapat dengan mudah dipahami, dan sesuai dengan pekerjaan yang dilakukan sebagai guru pendidikan agama Buddha. Validasi praktisi ini dilakukan dengan cara membahas tiap angket oleh guru maupun dosen, masukan atau bahasan dibandingkan dengan kisi-kisi instrumen, untuk dilihat kesesuaiannya. Validasi ini mempergunakan formula Aiken's V (Azwar, 2012; 134), yang ditujukan menghitung content-validity-coefficient, masing-masing instrumen dinilai oleh dua guru, dan tiga dosen. Hasil uji dapat dikatakan bahwa semua instrumen memiliki nilai koefisien yang tinggi, yaitu 0,75 sampai dengan 1 .

Sebagai hasil rangkuman berdasarkan penilaian guru maupun dosen, tentang kesesuaian dan keterbacaan angket dengan pelaksanaan tugas guru pendidikan agama Buddha dihasilkan bahwa, baik dari kesesuaian dan keterbacaan instrumen/angket dapat dikatakan baik. Berdasarkan hasil penilain ini menunjukkan bahwa instrumen/ angket tersebut dapat digunakan untuk uji dalam tahap selanjutnya.

Sebagai hasil telaah dan penggunaan angket untuk menilai pelaksanaan tugas guru pendidikan agama Buddha yang diampu 
oleh pembina agama menghasilkan serangkaian data sebagai berikut, bahwa guru dengan aktivitas tugas guru dalam pembelajaran dalam rangka membawa perkembangan peserta didik menjadi lebih dewasa secara mental spiritual maupun aspek fisik biologis. (Martinis dan Maisah, 2010:86). Dalam pendapatnya Pullias dan Young, Manan dan Yelon serta Weinstein dalam Mulyasa (2011: 37), diidentifikasi 19 peran guru, yakni guru sebagai pendidik, pengajar, pembimbing, pelatih, penasehat, pembaharu (inovator), model dan teladan, pribadi, peneliti, pendorong kreativitas, pembangkit pandangan, pekerja rutin, pemindah kemah, pembawa cerita, aktor, emansipator, evaluator, pengawet, dan sebagai kulminator. Dengan demikian peran guru sangat dominan dalam membentuk peserta didik menjadi manusia yang berkualitas. Tugas/kewajiban Guru menurut UndangUndang Nomor: 14 tahun 2005 pasal 20 adalah (1) merencanakan pembelajaran, melaksanakan proses pembelajaran yang bermutu, serta menilai dan mengevaluasi hasil pembelajaran, (2) meningkatkan dan mengembangkan kualifikasi akademik dan kompetensi secara berkelanjutan sejalan dengan perkembangan ilmu pengetahuan, teknologi, dan seni. (3) bertindak objektif dan tidak diskriminatif atas dasar pertimbangan jenis kelamin, agama, atau latar belakang keluarga dan status sosial ekonomi peserta didik dalam pembelajaran, (4) menjunjung tinggi peraturan perundang-undangan, hukum, dan kode etik guru, serta nilai-nilai agama dan etika; dan (5) memelihara dan memupuk persatuan dan kesatuan bangsa.

Sebagai bentuk hasil pengamatan terhadap guru tidak tetap, dapat dikatakan bahwa guru tersebut telah menjalankan proses dan prosedur yang diharapkan dalam pelaksanaan tugasnya. Semua guru telah menjalankan tugas yang menyerupai dengan guru tetapnya atau pegawai negeri. Tetapi sebagai kendala bagi mereka adalah tidak adanya penghasilan yang tetap atau tidak adanya jaminan bagi guru tidak tetap termasuk dalam hal gaji. Bentuk penyataan ini dapat membawa dampak terhadap sulitnya meningkatkan profesionalisme bagi mereka. Keberadaan mereka sebagai guru di lingkungan sekolah yang tidak memiliki guru tetap atau pegawai negeri sangat membantu proses belajar siswa, khususnya dalam memiliki pengetahuan agamanya. Tampak dari hasil proses belajar siswa memiliki keberhasilan. Hal ini dapat dilihat dari nilai yang 
diperoleh siswa selalu diatas standar minimal kelulusan materi agama, dan mereka para guru tidak tetap bukan sebagai pembuat naskah soal ujian, karena biasanya yang membuat adalah mereka yang memiliki status sebagai pegawai negeri sipil dan diberi tugas oleh dinas terkait. Menandakan bahwa mereka memiliki kemampuan dalam pelaksanaan tugas, tetapi penggunaan media serta strategi dalam pembelajarann yang masih relatif monoton.

\section{Tabel 1}

\begin{tabular}{ccccccc}
\hline Kls & K1 & K2 & K3 & K4 & K5 & Rata-Rata \\
\hline Gu 1 & 4 & 4 & 3 & 2 & 4 & 3,4 \\
Gu 2 & 3 & 4 & 3 & 3 & 4 & 3,4 \\
Gu 3 & 4 & 3 & 3 & 3 & 4 & 3,4 \\
Gu 4 & 4 & 4 & 3 & 3 & 4 & 3,6 \\
Gu 5 & 4 & 4 & 3 & 3 & 3 & 3,4 \\
Gu 6 & 4 & 3 & 2 & 2 & 3 & 2,8 \\
Gu 7 & 3 & 4 & 3 & 2 & 3 & 3 \\
Gu 8 & 4 & 4 & 3 & 3 & 3 & 3,4 \\
Gu 9 & 3 & 4 & 2 & 3 & 3 & 3 \\
Gu10 & 3 & 3 & 2 & 2 & 3 & 2,6 \\
& 3,6 & 3,7 & 2,7 & 2,6 & 3,4 & 3.57 \\
\hline
\end{tabular}

\section{Penilaian Kemampuan Guru Tidak Tetap}

Sumber : Data Primer yang diolah.

Perlunya perhatian terhadap guru dalam kemampuan penggunaan media serta strategi dalam pembelajaran, hal ini sangat terkait dengan gaji atau upah yang mereka terima yang tidak memiliki kepastian, dan berdampak dalam kreatifitas mereka khususnya dalam penggunaan media dan strategi pembelajaran. 
Berdasarkan Tabel 1 rata-rata tiap kemampuan atau kompetensi guru diatas 2, yang menunjukkan kemampuan mereka dalam pembelajaran secara umum sudah optimal. Nilai terendah dimiliki dalam hal kemampuan penggunaan startegi dan media pembelajaran. Nilai tertinggi terletak dalam hal penguasaan materi.

Berdasarkan wawancara bahwa secara umum yang menjadi keluhan mereka adalah berkaitan dengan belum memadainya nilai bantuan transport atau honor yang mereka terima, dan tidak adanya kepastian, sehingga berdampak terhadap kurangnya kreasi yang dihasilkan. Didukung pula dari observasi dan wawancara dihasilkan bahwa pembelajaran yang mereka selenggarakan tidak terfasilitasi dengan baik, khususnya dalam hal fasilitas disekolah, seperti tidak adanya ruang agama, tidak adanya buku pelajaran agama, sehingga kreasi guru diwujudkan dalam mengatasi permasalahan ruang, dan membuat materi pelajaran dengan lebih baik. Kenyataan yang disampaikan guru tersebut didukung dengan kenyataan bahwa buku pelajaran pendidikan agama Buddha tidak dijual bebas, artinya sulit untuk mendapatkan buku tersebut.

Keberhasilan guru dalam prestasi siswa lebih disebabkan karena memiliki tanggung jawab yang tinggi dalam mewujudkan pembelajaran, sekalipun honor mereka tidak memadai. Secara umum mereka menyampaikan sebagai perjuangan, dan adanya niat untuk mewujudkan pembelajaran dengan baik, dengan penguasaan materi yang cukup baik. Hal ini mempertegas bahwa kewajiban guru khususnya dalam pembelajaran merupakan hal yang utama, selain upaya dalam mencapai pengembangan profesi sebagai pendidik, dalam upaya meningkatkan kemampuan dalam melaksanakan tugas sebagai pendidik.

Melihat pada tugas mengajar yang dilaksanakan guru, yang berarti meneruskan dan mengembangkan ilmu pengetahuan dan teknologi. Dalam melaksanakan tugas tersebut, dengan mengingat tantangan pendidikan yang terus berubah, maka perlu dilakukan secara inovatif guna beradaptasi dan mengantisipasi perubahan masyarakat yang cepat serta berbagai kebijakan baru pemerintah dalam bidang pendidikan. Sehingga kreasi dan inovasi dalam media ataupun strategi harus diupayakan. 
Dalam pelaksanaan tugasnya, Guru menyadari akan etnik sosial-tugas dan kewajiban publik mereka yang dipresentasikan dalam pengajaran. Tampak bahwa pelaksanaan tugas guru dijalankan dengan optimal, baik dilihat dari observasi maupun data dari instumen. Guru bertanggung jawab pada tugasnya dalam hal mempromosikan proses belajar siswa, demikian juga terhadap pemahaman faktor seperti latar belakang, sikap dan cara belajar siswa, serta kemampuan dalam menciptakan lingkungan belajar yang efektif, dan memiliki standar profesional (Parkay, 2008: 38).

Tuntutan bagiguruadalahagar dapat mempergunakanketrampilan mengajarnya secara terpadu, serta menciptakan sistem lingkungan yang memungkinkan peserta didik dapat belajar secara efektif dan efisien. Dalam mengajar banyak interaksi terjadi antar komponen yang saling mempengaruhi dalam pencapaian tujuan pembelajaran (Suharjo, 2006: 85). Hal ini menjadi tuntutan agar guru kreatif dalam melakukan usahanya dalam proses pembelajaran. Mengajar tidak hanya sekedar menyampaikan pesan pembelajaran kepada peserta didik. Indikasi sebagai pelaksanaan tugas mengajar guru dapat berupa (1) Kelengkapan materi yang disajikan, (2) Penyampaian atau pengorganisasian materi. (3) Kesiapan materi guru dalam mengajar.

Guru dalam melaksanakan tugas pembelajaran agar berhasil secara efektif dan efisien melakukan kegiatan yang diantaranya disebutkan seperti dalam Undang-Undang Nomor: 14 Tahun 2005 yang merupakan komponen tugas guru dalam mengajar: (1) merencanakan pembelajaran, (2) melaksanakan proses pembelajaran yang bermutu, (3) menilai dan mengevaluasi hasil pembelajaran, (4) meningkatkan dan mengembangkan kualifikasi akademik dan kompetensi secara berkelanjutan sejalan dengan perkembangan ilmu pengetahuan, teknologi, dan seni. Pelaksanaan tugas guru dalam mengajar tersebut, harus didukung dengan tiga macam pengetahuan yaitu tentang diri, bahan pelajaran, pengetahuan tentang teori dan riset pendidikan. Hal ini berorientasi pada terciptanya lingkungan yang efektif dalam mengajar. (Parkay, 2008: 51).

Pengetahuan tentang diri akan berakibat pada pemahaman dengan baik atas siswanya. Seperti disampaikan oleh Arthur dalam Parkay (2008:51), yang mempelajari hubungan antara pemahaman 
pribadi guru dengan efektifitas profesional, menyatakan bahwa pemahaman dan penerimaan diri seorang guru akan membantu siswasiswanya mengenal dan menerima diri mereka. Evaluasi diri dimaksud terkait dengan emosi maupun bentuk pengaruh diri guru tersebut.

Memahami diri siswa, yang berarti memiliki pengetahuan tentang siswa, menunjukkan pemahaman guru atas diri siswa yang dapat meliputi pengetahuan tentang ketrampilan, bakat, gaya belajar, tingkat perkembangan, dan kesiapan siswa untuk belajar merupakan bagian penting dalam proses mengajar. Pemahaman guru atas siswa tersebut dapat menjadikan lebih berhasil proses mengajarnya. Kondisi tersebut dilaksanakan dengan cukup baik oleh para guru tidak tetap pendidikan agama Buddha.

Guru dengan tugas mengajar, yang diasumsikan bahwa mereka memiliki pengetahuan yang luas, selain pengetahuan dasar yang di miliki guru, maka seorang guru harus memiliki ketrampilan mengajar. Guru yang memiliki pengetahuan luas, tetapi tidak memiliki ketrampilan mengajar, maka proses mengajar akan tidak maksimal (Parkay, 2008: 51-54). Pelaksanaan tugas guru dalam mengajar dalam hal ini didahului dengan pemahaman atas diri sendiri, siswa maupun pengetahuannya, yang selanjutnya sesuai dengan tugas seorang guru mengaplikasikan ke dalam bentuk perencanaan mengajar, pelaksanaan proses mengajar serta evaluasi atas proses mengajar yang dilakukan. Kesemua proses harus berlangsung secara terus menerus.

Guru dalam pelaksanaan pengajarannya dapat berhasil, selain memulai dengan menciptakan perencanaan pembelajaran, juga mampu dan memiliki ketrampilan dasar mengajar. Kesemua komponen, dimulai dari pemahaman diri, perencanaan pembelajaran, serta pengetahuan dan kemampuan mengajar, merupakan kesatuan komponen yang dalam pelaksanaan tugas guru mengajar menjadi tuntutan untuk dipenuhi, dan dilaksanakan dalam wujud nyata proses mengajar. Tampak bahwa komponen tersebut dijalankan dengan optimal oleh guru tidak tetap tersebut. Sehingga proses mengajar berjalan efektif dan efisien sesuai dengan tujuan dari mengajar tersebut. 
Berdasarkan atas survai, secara terstruktur bagaimana guru dalam membuat rencana pembelajaran melalui pembuatan RPP, dihasilkan data berdasarkan komponen penilian rencana pembelajaran sebagai berikut: a) Kesesuaian dengan Standar kompetensidan kompetensi dasar, b)Kesesuaian rencana/tema pembelajaran. c) Kesesuaian bentuk rencana pembelajarannya, d) Kesesuaian media pembelajaran yang akan digunakan. e) Kesesuaian bentuk evaluasi yang akan digunakan

Terlihat dari komponen RPP terdapat kekurangan pada komponen ke tiga dan keempat, yakni berkaitan dengan strategi atau metode dan penggunaan media pembelajaran. Dengan urutan mulai kelas rendah ke besar, dengan permasalahan yang mirip yang terjadi tiap kelas. Hal ini menggambarkan perlunya pengenalan atau pelatihan dalam bidang kemampuan tersebut, sekalipun bukan berarti keadaan ini menunjukkan kekurangan, namun sebaliknya kemampuan gambaran ini memberikan perhatian agar dapat ditingkatkan, sehingga program pembelajaran dapat dicapai lebih maksimal. Komponen strategi atau metode pembelajaran, memiliki kekurangan secara umum pada poin b, e dan f. Yakni pada komponen bagian metode yang dipilih dan kesesuaiannya dengan materi, keadaan ini menggambarkan keadaan kebiasaan yang dilakukan guru dengan kecenderungannya, penetapan metode berdasarkan pertimbangan kemampuan siswa dan memberi pengayaan, merupakan suatu bagian keberhasilan proses pembelajaran, yang berarti proses pembelajaran akan dapat menjangkau secara menyeluruh siswa. Keadaan ini tergambarkan bahwa strategi atau metode hanya dicantumkan dan tidak sepesifik pada jenis materi, belum mempertimbangkan kemampuan siswa, dan bukan pada tujuan pengayaan. Kecenderungannya strategi bersesuaian dengan tujuan yang akan dicapai, pertimbangan waktu yang akan digunakan. Tentunya jika secara lengkap dari semua bagian maka pembelajaran akan lebih terintegrasi dengan hasil yang lebih maksimal.

Prinsip pengayaan dalam rencana pembelajaran harus ada, sehingga materi dapat selalu berkembang tidak pasif. Muatan motivasional, dapat menjadi satu dalam penggunaan metode yang tepat. Kemampuan atas komponen ini merupakan bagian dari kompetensi pedagogik, yang berarti guru harus memiliki penguasaan atas bagian tersebut. 
Tabel 2.

Perbandingan Komponen Rencana Pembelajaran

\begin{tabular}{|c|c|c|c|c|c|c|c|}
\hline 걱 & $\begin{array}{l}\vec{T} \\
O \\
\Xi \\
\end{array}$ & 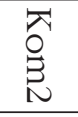 & $\begin{array}{l}\vec{T} \\
0 \\
⿱ \\
心\end{array}$ & 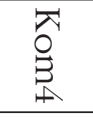 & $\begin{array}{l}\overrightarrow{\widehat{S}} \\
0 \\
\vec{G}\end{array}$ & $J m l$ & $\begin{array}{c}\text { Rata- } \\
\text { Rata }\end{array}$ \\
\hline$I I$ & 4 & 4 & 2.67 & 2 & 4 & 16.67 & 3.33 \\
\hline III & 4 & 4 & 3.00 & 3 & 4 & 18.00 & 3.60 \\
\hline IV & 4 & 4 & 3.67 & 3 & 4 & 18.67 & 3.73 \\
\hline \multirow[t]{3}{*}{ V } & 4 & 4 & 3.00 & 3 & 4 & 18.00 & 3.60 \\
\hline & 16 & 16 & 12.33 & 11 & 16 & 71.33 & 14.27 \\
\hline & 4 & 4.0 & 3.08 & 2.75 & 4.0 & 17.83 & 3.57 \\
\hline
\end{tabular}

Sumber : Data Primer, yang diolah

Tabel 3 yang menunjukkan pada tiap penilaian rencana pembelajaran, yang memuat masalah. Secara umum, keadaan ini tergambar dalam bagian b,e dan $\mathrm{f}$.

Tabel 3.

Penilaian Rencana Pembelajaran pada Komponen Strategi/Metode

\begin{tabular}{|c|c|c|c|c|c|}
\hline $\begin{array}{l}\underset{\mathscr{N}}{\mathbb{E}} \\
\underset{\sim}{*}\end{array}$ & $\frac{\overparen{T}}{\stackrel{\vec{D}}{D}}$ & 莺 & 忢 & 思 & Rata-Rata \\
\hline Data 1 & II & 3 & 2 & 3 & 2.7 \\
\hline Data 2 & III & 3 & 3 & 3 & 3.0 \\
\hline Data 3 & IV & 3 & 4 & 4 & 3.7 \\
\hline Data 4 & V & 3 & 3 & 3 & 3.0 \\
\hline Jumlah & & 12 & 12 & 13 & 12.3 \\
\hline Rata-Rata & & 3 & 3.0 & 3.25 & 3.1 \\
\hline
\end{tabular}

Sumber : Data Primer, yang diolah 
Tampak dalam tabel 2 permasalahan rencana pembelajaran ada pada komponen 3 dan 4, yang menunjukkan perlunya langkah perubahan agar terdapat penambahan kemampuan pada komponen tersebut.

Strategi atau Metode pembelajaan merupakan suatu keputusan bertindak dari guru dengan mempergunakan kecakapan dan sumber daya pendidikan yang tersedia, untuk mencapai tujuan melalui hubungan yang efektif antara lingkungan dan kondisi yang saling menguntungkan, kedua merupakan garis besar haluan untuk bertindak dalam mengelola proses belajar mengajar untuk mencapai tujuan pengajaran secara efektif dan efisien, dan ketiga merupakan pola umum perbuatan peserta didik didalam perwujudan kegiatan belajar-mengajar. Keempat, merupakan pola dan urutan tingkah laku guru untuk menampung semua variabel penting secara sadar dan sitematis. Dalam tabel 2 gambar 2, memiliki arti yang sama dengan pengertian keempat, dengan kenyataan bahwa rata-rata nilai dimiliki dengan rentang 2,7 sampai dengan 3,7, menggambarkan adanya kesulitan dalam membuat strategi pembelajaran, khususnya adalah pada kelas/tingkat rendah atau dua. Hal ini dapat disebabkan karena faktor kemampuan guru, atau terkait dengan materi dan model pembelajaran yang dijalankan. Berkaitan dengan pembelajaran tematik, dimungkinkan terjadi permasalahan, sekalipun bukan permasalahan yang cukup berarti, namun perlu menjadi pemahaman, agar dapat dilakukan perbaikan yang lebih sempurna.

Jika dilihat dari komponen pertama dan kedua, tidak terdapat permasalahan, dimungkinkan karena kesulitan dalam penyesuaian bentuk pembelajaran tematik pada kelas rendah, karena ada keadaan atau fakta nyata bahwa siswa dengan pembelajaran tematik, masih kesulitan dalam mengidentifikasi terkait dengan materi yang diberikan. Hal ini dapat dilihat dari bukti bahwa siswa kelas rendah masih dalam masa transisi, dan secara umum belum beradaptasi dengan baik, sehingga dimungkinkan guru dalam mencapai kesempurnaanya, justru akan menggalami kesulitan dalam aplikasi pembuatan rencana pembelajaran. 
Tabel 4.

Penilaian Rencana Pembelajaran pada Komponen Media Pembelajaran

\begin{tabular}{|c|c|c|c|c|c|}
\hline 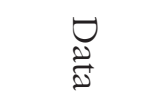 & $\frac{-1}{7}$ & 䲶 & 弚 & 元 & Rata-Rata \\
\hline Data 1 & II & 2 & 2 & 2 & 2.0 \\
\hline Data 2 & III & 3 & 3 & 3 & 3 \\
\hline Data 3 & IV & 3 & 3 & 3 & 3 \\
\hline Data 4 & $\mathrm{~V}$ & 3 & 3 & 3 & 3 \\
\hline Jumlah & & 11 & 11 & 11 & 11.0 \\
\hline Rata-Rata & & 2.75 & 2.8 & 2.75 & 2.8 \\
\hline
\end{tabular}

Sumber : Primer, yang diolah

Tampak dalam Tabel 4 bahwa komponen rencana pembelajaran pada media pembelajaran juga memiliki rata-rata lebih rendah jika dibanding dengan komponen tujuan pembelajaran, Materi pelajaran, dan evaluasi.

Kelemahan yang ada dalam pembuatan rencana pembelajaran berada pada indikator media yang belum menunjukkan dan menampakkan adanya penyesuaian dengan kondisi kelas, media belum memperlihatkan adanya penyesuaian dengan jenis evaluasi, media belum disesuaikan dengan kemampuan guru, serta media belum disesuaikan dengan kebutuhan dan perkembangan. Hal ini menggambarkan adanya kompetensi guru yang dimiliki belum dimunculkan secara penuh. Media yang digunakan secara umum masih bersifat monoton, atau seperti biasanya, tidak mencerminkan adanya perubahan. Jika dilihat dan dikaitkan dengan evaluasinya, belum tampak hubungan antara media dengan evaluasinya, sedangkan evaluasi secara umum terkait hanya pada sisi materi, belum memperhitungkan komponen yang menyertai dalam proses pembelajaran.

\section{Strategi Pembelajaran}

Strategi pembelajaran berhubungan dengan cara-cara yang dipilih guru untuk menyampaikan materi pembelajaran dalam 
lingkungan pembelajaran tertentu, mencakup sifat lingkup, dan urutan kegiatan yang dapat memberikan pengalaman belajar kepada siswa. Strategi pembelajaran merupakan kegiatan yang dipilih guru dalam proses belajar mengajar, yang dapat memberikan kemudahan-kemudahan atau memfasilitasi siswa sehingga dapat mencapai tujuan yang diharapkan.

Hasil data menunjukkan bahwa guru melakukan pembelajaran secara umum berdasarkan yang biasa dilakukan. Permasalahan pokok berdasarkan data yang didapatkan dengan melihat proses pembelajaran khususnya pada persiapan pembelajaran, melalui penilaian rencana pembelajaran, dapat memberikan gambaran bahwa terdapat kesulitan untuk mengintegrasikan komponen dalam proses pembelajaran, sehingga perlu arahan dan pembinaan, sehingga program pembelajaran dapat dicapai secara optimal.

Kajian kesulitan, dimungkinkan karena penggunaan model tematik, yang memiliki perbedaan dengan model yang biasa dilakukan. Dalam pembelajaran tematik, memang sesungguhnya harus menkolaborasikan berbagai komponen tujuan pembelajaran, dengan berbagai perangkatnya dalam mencapai tujuan pembelajaran yang berdiri sendiri. Berdasarkan atas pengamatan ini, dirasakan adanya tingkat kesulitan dalam program pembelajaran temataik tersebut.

\section{Media Pembelajaran}

Media pembelajaran merupakan salah satu dari komponen integral dalam sistem pembelajaran. Media sebagai pembawa informasi dari guru ke peserta didik, hal ini berarti media merupakan hal yang sangat penting, dalam menuju tujuan pembelajaran, agar dapat tercapai secara efektif dan efisien. Tiga kemampuan media pembelajaran, seperti kemampuan menampilkan kembali suatu objek atau kejadian, menampilkan berbagai objek dari berbagai macam perubahan, dapat menjangkau audien yang sangat banyak. Jenis media pembelajaran sangat banyak dan beragam, yang masingmasing memiliki keungulan dan kelemahan, sehingga penggunaan media akan sangat baik jika memperhatikan karakteristik peserta didik, strategi pembelajaran, organisasi kelompok belajar, alokasi 
waktu, dan sumber, prosedur pemilihannya, ketersediaan sumber belajar, ketersediaan dana, keluwesan, kepraktisan, ketahanan, efektivitas biaya, tenaga dan waktu. Sehingga pemilihan media akan efektif dan efisien, dan bukan berdasarkan kebiasaan.

\section{Kesiapan Pelaksanaan Pembelajaran oleh Guru Dalam Kelas}

Keadaan yang telah dilakukan berkaitan dengan program yang direncanakan, yakni berstandarkan pada kurikulum, yang diturunkan dalam silabus, yang disesuaikan dengan keadaan lingkungan yang ada dalam kelas, serta aspek kemampuan dan daya dukung yang dimiliki. Pembelajaran yang dilakukan telah dirancang pada standar proses, yang harus memperhatikan kegiatan-kegiatan minimal pembelajaran. Guru memahami kondisi lingkungannya, termasuk dalam hal ini telah dilakukan eksplorasi, yang merupakan kegiatan untuk melibatkan peserta didik dalam mencari informasi yang luas mengenai materi yang sedang dipelajari dari berbagai sumber belajar, baik dalam lingkungan sekolah maupun lainnya. Penggunaan metode oleh guru, dapat bermacam-macam, sesuai dengan kebutuhan, baik dilihat dari siswa, materi, waktu, lingkungan, tujuan, kontek maupun berbagai hal, sehingga proses pembelajaran dapat dicapai secara optimal.

Penggunaan Rencana pembelajaran merupakan rangkaian dalam penerapan program pembelajaran (RPP) yang merupakan aktualisasi silabus. Sehingga guru dalam pembuatan RPP harus memiliki pemahaman atas kurikulum dan silabus yang sebelumnya telah disusun. Secara umum guru telah memahami bagaimana membuat rencana pembelajaran, termasuk dalam hal ini RPP.

Dalam penyusunan Silabus atupun RPP terdapat beberapa hal yang dapat berpengaruh seperti pemahaman guru, latar belakang guru, pengalaman mengajar, siswa, sarana prasarana yang ada baik sekolah maupun guru, ataupun lingkungan, kesemuanya merupakan komponen yang seharusnya menjadi perhatian, sehingga proses pembelajaran dapat optimal, dimana RPP merupakan realisasi dari pengalaman belajar siswa yang telah ditetapkan dalam silabus pembelajaran. Hal yang terjadi di tempat 
tugas guru pendidikan agama Buddha, dengan, secara umum telah melakukan antisipasi atas proses yang seharusnya ada pada perencanaan pembelajaran. Komponen RPP meliputi : a) Identitas mata pelajaran (kelas, semester dan waktu/banyaknya jam pertemuan yang dialokasikan). b) Kompetensi dasar dan indikator yang akan dilaksanakan. c) Materi pokok beserta uraiannya, d) Strategi pembelajaran (kegiatan pembukaan, inti dan penutup). e) Alat dan media f) Penilaian dan tindak lanjut g) Sumber belajar, melalui daftar pustaka.

RPP seharusnya lebih lengkap dimulai dari tahap perangkat RPP, yang merupakan perangkat rencana pembelajaran yang terdiri dari Silabus, RPP, LKS, Kunci LKS, Tabel Spesifikasi atau Kisi-kisi Lembar Penilaian, Lembar Penilaian, Kunci Lembar Penilaian, Buku Siswa, dan Media. Kebanyakan guru menilai RPP masih terbatas pada perangkat RPP, tanpa dan belum membandingkan dengan LKS, ataupun Buku Siswa. Sehingga persiapan pembelajaran oleh guru masih terbatas pada silabus dan RPP, sedangkan komponen LKS, maupun pembahasan lanjutan terkait dengan evaluasi hasil belajar atau penilaian, belum memiliki gambaran secara lengkap dengan penilaian melalui validitasnya.

Sebagai gambaran dari saran dan masukan dalam diskusi memberikan indikasi atas apa yang seharusnya dilakukan dalam melakukan evaluasi rencana pembelajaran secara menyeluruh, sehingga penilaian rencana pembelajaran dapat secara lengkap dan utuh, dan merupakan keterpaduan.

Alasan LKS belum masuk dalam program rencana pembelajaran, hal ini disebabkan atas keadaan bahwa guru biasanya mempergunakan LKS secara bersama dalam batasan rayon atau wilayah koordinasi dinas yang ada, sehingga mempergunakan produk LKS dari karya lembaga penerbitan tertentu. Hal ini memberikan gambaran sebagai saran kedepan untuk menjadikan program rencana pembelajaran menjadi kesatuan dengan lembar kegiatan siswa. 


\section{Kesimpulan}

Pelaksanaan pembelajaran yang dilakukan oleh pembina agama melalui guru tidak tetap pendidikan agama Buddha dalam upaya memenuhi jumlah kebutuhan guru cukup optimal. Seluruh guru (pembina agama) telah menjalankan tugasnya dengan baik, dengan komponen yang harus mendapat perhatian secara khusus adalah dalam hal penggunaan media dan atau strategi belajar. Sebagai simpulan atas evaluasi program pembelajaran adalah sebagai berikut : 1) Jika evaluasi dilakukan secara menyeluruh dalam proses rencana pembelajaran maka terlihat adanya kurang lengkapnya rencana pembelajran yang dilakukan seperti dalam hal pembuatan LKS, kejelasan sumber, belum adanya pokok bahasan validitas isi, dan jika dilihat hanya pada proses rencana pembelajaran pada khususnya RPP (khusus pada rencana pembelajaran dalam kelas, dengan tanpa melihat aspek yang lain) dihasilkan kekurangan dalam hal metode dan strategi pembelajaran yang dipergunakan. 2) Pemahaman guru atas kondisi lingkungannya, termasuk dalam hal ini perlu adanya eksplorasi, yang merupakan kegiatan untuk melibatkan peserta didik dalam mencari informasi yang luas mengenai materi yang sedang dipelajari dari berbagai sumber belajar, baik dalam lingkungan sekolah maupun lainnya. Penggunaan metode oleh guru, dapat bermacam-macam, sesuai dengan kebutuhan, baik dilihat dari siswa, materi, waktu, lingkungan, tujuan, kontek maupun berbagai hal, sehingga proses pembelajaran dapat dicapai secara optimal. 3) Penggunaan Rencana pembelajaran merupakan rangkaian dalam penerapan program pembelajaran (RPP) yang merupakan aktualisasi silabus. Sehingga guru dalam pembuatan RPP seharusnya memiliki pemahaman atas kurikulum dan silabus yang sebelumnya telah disusun, dengan kriteria yang menyertainya, dengan berbagai pertimbangan yang menyertainya.

\section{Daftar Pustaka}

Amin, Hafeez Ullah, Khan Abdur Rashid. 2009. Acquiring Knowledge for Evaluation of Teachers' Performance in Higher Education - using a Questionnaire. (IJCSIS) International Journal of Computer Science and Information Security, Vol. 2, No. 1, 2009. 
Armida S. Alisjahbana, et al. 2010. Laporan Pencapaian Tujuan Pembangunan Milenium di Indonesia Tahun 2010. Kementerian Perencanaan Pembangunan Nasional / Badan Perencanaan Pembangunan Nasional (BAPPENAS).ISBN 978 - 979 - 3764 - 64 - 1. (www.depkeu.go. id/ind/.../MP3EI_ revisi-complete _(20mei11).pdf).

Azwar, S. (2010). Penyusunan skala psikologi. (1st ed). Yogyakarta: Pustaka Pelajar.

--.(2013). Penyusunan skala psikologi, .(2nd ed). Yogyakarta: Pustaka Pelajar.

Cipta Jaya Jakarta, 2007. Peraturan Menteri Pendidikan Nasional Republik Indonesia No. 16 Tahun 2007 tentang Standar Kualifikasi Akademik dan kompetensi Guru.

Daniel Suryadarma, Asep Suryahadi \& Sudarmo Sumarto. 2005. Penentu Kinerja Murid Sekolah Dasar di Indonesia, Semeru, Yertas Verja (World Bank).

Danim Sudarwan. 2002. Inovasi Pendidikan dalam upaya Peningkatan profesionalisme Tenaga Kependidikan. Bandung: Pustaka Setia.

Gordon, Robert, et.all. 2006, Identifying Effective Teachers Using Performance on the Job, Discustion paper electronic, 2006 - 01.

Martinis Yamin, \& Maisah. 2010. Standardisasi Kinerja Guru,Gaung Persada Jakarta

Mulyasa, E. 2011. Menjadi Guru Profesional. Remaja Rosdakarya, Bandung. Parkay F.W. \& Stanford, B.H. 2008. Menjadi Seorang Guru. (Terjemahan Dani Dharyani). Pearson Education, 75 Arlington Street, Boston.(Buku asli diterbitkan tahun 2008.

Standar Nasional Pendidikan (SNP) 2006. Jakarta: Asa Mandiri.

Suharjo, M.S. 2006. Mengenal Pendidikan Sekolah Dasar,Teori dan Praktek. Departemen Pendidikan Nasional, Jakarta.

Rusidi, 2009. Undang-undang No. 14, Tahun 2005 Tentang Guru dan Dosen

Undang-Undang No. 20 Tahun 2003 tentang Sistem Pendidikan Nasional Undang-Undang Nomor 17 Tahun 2007tentang Rencana Pembangunan Jangka Panjang 